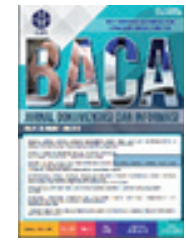

\title{
Information literacy level of State University of Malang students participant in National Students Scientific Week 2018-2019
}

\author{
Mutia Indriyani $^{1 *}$; Moh. Safii ${ }^{2}$; Yuni Pratiwi ${ }^{3}$ \\ ${ }^{1,2,3}$ Department of Indonesian Literature, State University of Malang \\ "Correspondence: moh.safii@um.ac.id
}

Diajukan: 09-11-2020; Direview: 26-01-2021; Diterima: 21-04-2021; Direvisi: 25-06-2021

\begin{abstract}
This study aimed to describe the level of literacy information of State University of Malang students participants in PIMNAS 2018 and 2019 based on six standards of literacy information. This research used descriptive research method with a quantitative approach. The results showed that the information literacy level of the State University of Malang students who participated in the PIMNAS 2018 and 2019 based on six sub-variables, there are average score of identifying information needs was 3.43; average score of information-searching behavior and information sources was 3.15; average score of information search techniques and strategies was 2.96; average score of information organization and evaluation was 3.19; average score of information use and related issues was 3.14; and average score of information sharing and knowledge creation was 3.76. The author argue that the State University of Malang Library should be involved in improving student literacy in the category of using techniques and information search strategies.
\end{abstract}

\begin{abstract}
ABSTRAK
Penelitian ini bertujuan untuk mendeskripsikan tingkat kemampuan literasi informasi mahasiswa Universitas Negeri Malang peserta PIMNAS tahun 2018 dan 2019 berdasarkan enam standar literasi informasi. Metode penelitian yang digunakan adalah penelitian deskriptif dengan pendekatan kuantitatif. Hasil penelitian menunjukkan bahwa kemampuan literasi informasi mahasiswa Universitas Negeri Malang peserta PIMNAS tahun 2018 dan 2019 berdasarkan enam sub-variabel yaitu: nilai rata-rata identifikasi kebutuhan informasi yaitu 3,43; nilai rata-rata perilaku pencarian informasi dan sumber informasi yaitu 3,15; nilai rata-rata teknik dan strategi pencarian informasi yaitu 2,96; nilai rata-rata organisasi dan evaluasi informasi yaitu 3,19; nilai rata-rata penggunaan informasi dan isu-isu terkait yaitu 3,14; dan nilai rata-rata berbagi informasi dan penciptaan pengetahuan yaitu 3,76 . Penulis berpendapat bahwa perlu adanya keterlibatan dari Perpustakaan Universitas Negeri Malang untuk meningkatkan literasi mahasiswa dalam kategori penggunaan teknik dan strategi pencarian informasi.
\end{abstract}

Keywords: Information literacy; Information retrieval; Searching strategies; User needs; Academic library

\section{INTRODUCTION}

All aspects of people's life are now influenced by the development of information technology, ranging from economic, social, cultural aspects to ethics and morality in the nation and state. The presence of information technology makes it easier for everyone to access information trough the internet anywhere and anytime. The information available on the internet has many benefits, but there is also a lot of information that is not. Therefore, everyone needs information literacy skills so that they become smarter and wiser in sorting out useful information in solving problems. This is in line with American Library Association (ALA) which states that information literacy skills 
needed someone to be aware of when information is needed and has the ability to find, evaluate and use the information needed effectively.

Information literacy skills are important to be mastered by every individual, especially students because by mastering these skills students can participate in supporting the achievement of the Tri Dharma of Higher Education, especially the pillars of research and development as well as community engagement. One of the activities that support that is the National Student Scientific Week (PIMNAS) in which there is an activity to make scientific works in the form of the Student Creativity Program (PKM). This activity is a forum for students to hone their potential in making scientific papers that aim to study, develop, and apply science and technology to the wider community (Lembaga Layanan Pendidikan Tinggi Wilayah XI Kalimantan, 2018).

Program Kreativitas Mahasiswa requires students to have the ability to think critically, creatively, and innovatively, so that by mastering information literacy skills students can hone these abilities to support the learning process in higher education. Information literacy skills can make a person not only able to access information correctly, but also requires someone to understand what their information needs are, how to determine information relevant to the problem at hand, how to select information sources according to their needs, how to organize information, and how to process this information into new information and knowledge that is useful for others (Pattah, 2014). Furthermore, Lasa Hs (2009) defines information literacy as awareness of information needs, identifying, accessing effectively and efficiently, evaluating, and legally incorporating information into knowledge and communicating this information, this awareness can later support the development of a lifelong learning process an individual.

Student's information literacy can be measured using standards from various countries, such as the Association of College and Research Libraries (ACRL) from the United States, the American Library Association (ALA) from Canada, the Information Literacy Standards from CAUL (The Council of University Librarians) from Australia \& New Zealand, Seven Pillars of Information Skills by SCONUL (The Standing Committee for National and University Libraries) from the UK, and Information Literacy Guidelines from Singapore (Mokhtar, Majid, \& Foo, 2004). Information literacy level of State University of Malang students who participated in PIMNAS 2018-2019 was measured using information literacy standards developed by Intan Azura Mokhtar, Shaheen Majid, and Schubert Foo which consisted of skills to identify information needs, information-seeking behavior and information sources, techniques and strategies information retrieval, organization and evaluation of information, information use and related issues, and sharing of information and creation of new knowledge. These information literacy standards emphasize the aspects of fulfilling needs and creating information ethically, effectively and efficiently and are developed because these standards are useful as tools for preparing competency instruments in measuring or evaluating information literacy skills in educational settings (Mokhtar, Majid, \& Foo, 2004).

Several studies that are similar to this research topic, first, research by Devina (2018) on information literacy of STEI SEBI students using the information literacy model The Empowering Eight. The results of this quantitative descriptive study indicate that the literacy skills of STEI SEBI students are good and there are efforts from the library to improve student information literacy, namely in the form of library education and information literacy workshops called INSERT workshops. Second, research by Syahrir (2013) on information literacy undergraduate study program students of Accounting (Semester VIII/Academic Year 2012/2013) Faculty of Economics, Hasanuddin University Makassar uses the Information Literacy Competency Standard for Higher Education model from the Association of College and Research Libraries (ACRL). The results of the descriptive qualitative research indicate that the students' information literacy skills are quite good. 
This research is important because information literacy skills are a basic provision that must be possessed by the academic community, especially in the current era of information technology, information literacy can be used as a support for the lifelong learning process and the learning process, one of which is the activity of creating scientific works in the PIMNAS event. Therefore, the author determines the title "Information Literacy Level of State University Of Malang Students Participant in National Student Scientific Week (PIMNAS) 2018-2019" aims to determine the literacy level of State University of Malang students who participating in PIMNAS 2018-2019.

\section{LITERATURE REVIEW}

\subsection{Information Literacy}

The skills that everyone must have in information literacy according to UNESCO in the Information for All Program (2008) are skills in knowing information needs, finding and evaluating the quality of information obtained, organizing and retrieving information, creating and utilizing information ethically and effectively, and communicate this knowledge to others. Diehm \& Lupton (2014) states that information literacy is a set of skills and knowledge of an individual in finding information which includes knowledge related to information sources, skills to evaluate information, and the ability to use information and communication technology. The ability to use information and communication technology is one of the skills that must be possessed in information literacy because currently the role that information and communication technology has is very large in completing human tasks and jobs.So, information literacy can be concluded as an ability to understand information needs, determine information relevant to the problems, select information sources, organize information, and the ability to use information and communication technology so that information can solve problems.

\subsection{Information Literacy Standards}

\subsubsection{Identification of information need}

Information needs arise when individuals realize that there is a lack of understanding in themselves in seeking answers to the questions at hand (Batley, 2007). Furthermore, Sulistyo-Basuki (2004) writes that information needs are information desired by a person, to fulfill information needs related to work, research, spiritual satisfaction and education. The need for information is a desire that arises because a person realizes that there is a deficiency between the knowledge they have and what they need in themselves, the information needed for the purpose of education, research, work, and spiritual satisfaction. This proves that everyone's information needs are different, a person's information needs depend on what goals are to be achieved. Identification of information needs means determining what information is needed in solving the problems at hand.

\subsubsection{Information-seeking behavior and information sources}

Information-seeking behavior is an information search activity carried out to meet a particular need (Spink \& Cole 2006). An individual in fulfilling the information needs to increase knowledge will show different search behavior with people whose purpose is to find information to entertain. Someone who needs information to increase knowledge will prioritize information that is guaranteed to be true, accurate, and up to date.Information-seeking behavior according to Wilson (2000) is a basic behavior that a person has when dealing with an information system. The scope of informationseeking behavior includes physical activities such as clicking links, using Boolean Operators or using certain benchmarks in determining the level of conformity of the information required. There are several things that influence a person in the activity of finding the information needed, namely a person's psychological condition, demographics, roles in society, environment, and characteristics of information sources or media used to find information (Case, 2002). 


\subsubsection{Information-seeking techniques and strategies}

The information search strategy according to Purwono (2008) is a search that is carried out in a structured manner and involves various ways of utilizing keywords, phrases, document subjects, using Boolean Operators (AND, OR, and NOT) and other search tools contained in each search engine. This indicates that searching for information in cyberspace requires skills in the field of computer and information technology. The purpose of using information-seeking techniques and strategies is to obtain information that is relevant or as needed and to avoid finding information that is too broad and too narrow (Rupadha, 2010). By using information-seeking techniques and strategies, information can be obtained quickly and accurately.

\subsubsection{Organization and evaluation of information}

Organizing information into personal storage media is one strategy for dealing with the amount of information stored (Warlick \& Armstrong, 2004). Organizing information based on certain criteria, can make it easier to find information when the information is needed. Warlick \& Armstrong (2004) also states that evaluation of information is the ability to analyze information to determine its usefulness. The use of each information is different, depending on the purpose of the creation of the new information and knowledge. In information literacy, the information that has been found is evaluated to make it easier for students to determine information that is appropriate to the topic and subject of their research.

\subsubsection{Information use and related issues}

One of the reasons for the need for information by every individual is due to completing a scientific research, because of the demands of a job or profession and because of one's interest in a particular subject (Voight in Krikelas, 1983). Therefore, students must pay attention to ethics in writing scientific papers so that the information created is not considered plagiarism. The following are issues related to the creation of scientific works, including ethics in the creation of information and knowledge, such as how to cite, refer, and write a list of references. This is important to note because if someone who quotes someone else's work without including the source of the quote is considered plagiarism. Warlick \& Armstrong (2004) also states that one of the new skills a person must have in information literacy is ethics, where ethics is defined as how to use information ethically in various social contexts, one of which is writing or citing sources cited.

\subsubsection{Information sharing and knowledge creation}

Information and knowledge need to be disseminated so that the information and knowledge that has been created can be known by many people and can add to someone's insight regarding a particular field of knowledge. Setiarso (2006) also states that research is a process of creating new knowledge and becomes an element of efforts in the world of education to obtain scientific solutions to human problems. So, information and knowledge need to be disseminated so that it is useful for others.

\subsection{Program Kreativitas Mahasiswa (PKM)}

Program Kreativitas Mahasiswa (PKM) is an effort formed by the Ditjen Belmawa to cultivate, accommodate, and realize creative and innovative ideas of Indonesian students in studying, developing, and applying the knowledge and technology learned during lectures to the wider community (Kementerian Riset \& Teknologi, 2018). Before students can take part in PIMNAS, there are stages that PKM 5 Fields must go through based on the provisions set by Ristekdikti starting with the preparation of proposals by students until the final activity is a presentation of PKM results at the PIMNAS event. Making students know and obey the rules, creative, and innovative as well as cooperative objective is the goal of developing PKM by Ristekdikti. This goal is in line with the benefits obtained by students who have information literacy skills. Information literacy is useful for honing students' critical, logical, and creative thinking skills to solve problems. This is in line 
with the benefits of PKM activities, namely PKM can develop students higher-order thinking skills, creative thinking, and critical thinking skills. Information literacy is related to PKM because this activity is one of the implementations of information literacy in the higher education environment.

\section{METHODS}

This research is a descriptive research with a quantitative approach. The population and sample in this study were students of the State University of Malang who participated in the 2018 and 2019 PIMNAS, totaling 69 students. The data collection method was carried out using a research instrument in the form of a questionnaire. The research instrument was tested for validity using the IBM SPSS Statistic 25. After rcount was obtained, rcount was compared with $r$ table that had been determined with a significance level of 5\%. A statement/question item is said to be valid if $r$ count $>\mathrm{r}$ table and a statemen/question item is said to be invalid if rcount $<\mathrm{r}$ table.

The reliability test used the Alpha Cronbach technique with the help of the IBM SPSS Statistic 25 software. Based on the reliability test results it was known that 24 items were declared very strong. Data analysis was also carried out systematically through statistical calculations using the help of IBM SPSS Statistic 25 software, then analyzed using the calculation of the percentage formula, Likert scale, and interval scale. The interpretation of each answers are (1) always is given a score of 4, (2) often is given a score of 3, (3) sometimes is given a score of 2, (4) never is given a score of 1 .

Average rating criteria were determined using an interval scale (Sudjana, 2005).

$$
\begin{array}{ll}
\mathrm{I}=(\mathrm{H}-\mathrm{L}): \mathrm{N} \\
\mathrm{I} & =\text { Interval class length } \\
\mathrm{H} & =\text { Highest score } \\
\mathrm{L} & =\text { Lowest score } \\
\mathrm{N} & =\text { Number of interval classes }
\end{array}
$$

$$
\begin{gathered}
\mathrm{I}=(4-1) / 4 \\
\mathrm{I}=3 / 4=0,75
\end{gathered}
$$

So, the length of the interval class is 0.75 . the classification criteria for the average of each information literacy standard can be seen in table 1 .

Table 1 Classification of Average Rating Criteria

\begin{tabular}{cc}
\hline Score & Criteria \\
\hline $3,27-4,02$ & Very good \\
\hline $2,51-3,26$ & Good \\
\hline $1,75-2,50$ & Respectable \\
\hline $1,00-1,74$ & Deficient \\
\hline
\end{tabular}

\section{RESULT AND DISCUSSION}

\subsection{Information Literacy: Identification Information Needs}

The first standard of information literacy skills formulated by Mokhtar, Majid, \& Foo in 2004 is the ability to identify information needs. The statement given in the sub-variable of the ability to identify this information needs amounts to two statements. 
Table 2. Statistic of Identifying Information Needs

\begin{tabular}{ccccccc}
\hline & Never & $\begin{array}{c}\text { Some- } \\
\text { times }\end{array}$ & $\begin{array}{c}\text { Of- } \\
\text { ten }\end{array}$ & $\begin{array}{c}\text { Al- } \\
\text { ways }\end{array}$ & $\begin{array}{c}\text { Total } \\
\text { Aver- } \\
\text { age }\end{array}$ \\
\hline Topic determination ( keywords ) & 2 & 2 & 8 & 26 & 38 & 3.53 \\
\hline $\begin{array}{c}\text { Determination of the formulation of } \\
\text { the problem }\end{array}$ & 2 & 2 & 10 & 21 & 38 & 3.32 \\
\hline Overall average & $\mathbf{3 . 4 3}$ & & & & & \\
\hline-
\end{tabular}

The first statement, 26 respondents $(68.4 \%)$ chose always, eight respondents $(21.1 \%)$ chose often, two respondents (5.3\%) chose sometimes and never. Meanwhile, in the second statement, 21 respondents (55.3\%) tended to choose always, ten respondents (26.3\%) chose often, five respondents $(13.2 \%)$ chose sometimes, and two respondents $(5.3 \%))$ choose never. The average value obtained is 3.43 in the very good category.

The results showed that the first standard of information literacy regarding the identification of information needs has a very good average value. After the research topic was determined, the PIMNAS participant students then determined the formulation of the problem so that they could start looking for information effectively and efficiently, obtaining accurate, up-to-date and relevant information with the research topic. This is in line with what was stated by the Association of College and Research Libraries (2000) students who are literate are those who can formulate basic questions for their information needs, understand information sources to make it easier to find the topic being sought, define information needs, then identify keywords or a term used to find the information needed by participating in class discussions, joining work groups or discussing using chat applications.

\subsection{Information Literacy: Information Searching Behavior and Information Sources}

The second standard is information seeking behavior and information sources. Statements given to this sub-variable total seven statements.

Table 3. Statistics of Information Searching Behavior and Information Sources

\begin{tabular}{|c|c|c|c|c|c|c|}
\hline & Never & $\begin{array}{l}\text { Some- } \\
\text { times }\end{array}$ & $\begin{array}{l}\text { Of- } \\
\text { ten }\end{array}$ & $\begin{array}{l}\text { Al- } \\
\text { ways }\end{array}$ & $\begin{array}{l}\text { To- } \\
\text { tal }\end{array}$ & Average \\
\hline Tracing previous research & - & 3 & 13 & 22 & 38 & 3.50 \\
\hline $\begin{array}{l}\text { Internet access (journals, articles and } \\
\text { websites) }\end{array}$ & - & - & 11 & 27 & 38 & 3.71 \\
\hline Use of printed information sources & $\begin{array}{l}3 \\
9 \\
18 \\
8 \\
38 \\
2.82 \\
\end{array}$ & & & & & \\
\hline Use of primary information sources & - & 3 & 17 & 18 & 38 & 3.39 \\
\hline $\begin{array}{l}\text { Use of secondary sources of informa- } \\
\text { tion }\end{array}$ & 3 & 13 & 15 & 7 & 38 & 2.68 \\
\hline Use of tertiary information sources & 4 & 15 & 14 & 5 & 38 & 2.53 \\
\hline $\begin{array}{l}\text { Information tracking based on the } \\
\text { level of accuracy and recency }\end{array}$ & 1 & - & 19 & 18 & 38 & 3.42 \\
\hline Overall Average & 3.15 & & & & & \\
\hline
\end{tabular}

The first statement, as many as 22 respondents (57.9\%) chose always, thirteen respondents (34.2\%) chose often and three respondents $(7.9 \%)$ chose sometimes. The second statement, the tendency of respondents to choose answers always and often with the respective percentages of 
27 respondents $(71.1 \%)$ and eleven respondents $(28.9 \%)$. The third statement, as many as eight respondents $(21.1 \%)$ chose always, eighteen respondents $(47.4 \%)$ chose often, nine respondents $(23.7 \%)$ chose sometimes and three respondents $(7.9 \%)$ chose not ever. The fourth statement, as many as eighteen respondents $(47.4 \%)$ chose always, seventeen respondents $(44.7 \%)$ chose often and three respondents $(7.9 \%)$ chose sometimes.

The fifth statement, as many as seven respondents (18.4\%) chose always, fifteen respondents (39.5\%) chose often, thirteen respondents $(34.2 \%)$ chose sometimes and three respondents $(7.9 \%)$ chose never. The sixth statement, as many as five respondents $(13.2 \%)$ chose always, fourteen respondents (36.8\%) chose often, fifteen respondents (39.5\%) chose sometimes and four respondents $(10.5 \%)$ chose never. The seventh statement, as many as eighteen respondents (47.4\%) chose always, nineteen respondents $(50 \%)$ chose often, and one respondent $(2.6 \%)$ chose never. The average value obtained is 3.15 with good category.

Based on the results of the study, the average score of the PIMNAS participant students on the second standard of information literacy about search behavior and information sources is categorized as good. Based on the research results, it is known that the PIMNAS participant students used previous research to obtain examples of PKM writing, made use of libraries, e-journals, and used primary, secondary and tertiary information sources according to their information needs. This shows that students' information seeking behavior is influenced by their information needs. If the information needed is not available in the library, they will look it up in e-journals.

As stated by the Association of College and Research Libraries (2000) literate students are able to limit the information retrieval process according to information needs, think about steps to find information, and formulate a realistic budget and time limits to obtain the information needed.

\subsection{Information Literacy: Information Search Techniques and Strategies}

The third standard is determining the techniques and strategies for information retrieval. The statements given to this sub-variable total five statements.

Table 4. Statistics of Information Search Techniques and Strategies

\begin{tabular}{lllllll}
\hline & Never & $\begin{array}{l}\text { Some- } \\
\text { times }\end{array}$ & $\begin{array}{l}\text { Of- } \\
\text { ten }\end{array}$ & Always & $\begin{array}{l}\text { To- } \\
\text { tal }\end{array}$ & $\begin{array}{l}\text { Aver- } \\
\text { age }\end{array}$ \\
\hline Utilization of the library & 10 & 14 & 10 & 4 & 38 & 2.21 \\
\hline $\begin{array}{l}\text { Use of OPAC (Online Public Access } \\
\text { Catalog) }\end{array}$ & 7 & 9 & 10 & 12 & 38 & 2.71 \\
\hline Access e-journal & - & 2 & 11 & 25 & 38 & 3.61 \\
\hline Simple search strategy usage & - & 3 & 19 & 16 & 38 & 3,34 \\
\hline Use of advanced search strategies & 1 & 10 & 18 & 9 & 38 & 2,92 \\
\hline Overall average & $\mathbf{2 . 9 6}$ & & & & & \\
\hline
\end{tabular}

The first statement, four respondents (10.5\%) chose always, ten respondents $(26.3 \%)$ chose frequently, fourteen respondents $(36.8 \%)$ chose sometimes and ten respondents $(26.3 \%)$ chose not ever. The second statement, as many as twelve respondents (31.6\%) chose always, ten respondents (26.3\%) chose often, nine respondents $(23.7 \%)$ chose sometimes and seven respondents $(18.4 \%)$ chose not ever. The third statement, as many as 29 respondents $(65.8 \%)$ chose always, eleven respondents (28.9\%) chose often and two respondents (5.3\%) chose sometimes. The fourth statement, as many as sixteen respondents $(42.1 \%)$ chose always, nineteen respondents $(50 \%)$ chose often and three respondents $(7.9 \%)$ chose sometimes. The fifth statement, as many as nine respondents $(23.7 \%)$ chose always, eighteen respondents $(47.4 \%)$ chose often, ten respondents $(26.3 \%)$ chose sometimes and one respondent $(2.6 \%)$ chose not ever. The average value obtained is 2.96 with good category. 
The results showed that the third standard of information literacy about determining information retrieval techniques and strategies has a good average value. Purwono (2008) states that there are four reasons why a search strategy on the internet must be determined before starting to look for information, first, the information available on the internet is countless, extensive and various types; second, to obtain appropriate information; third, search time efficiency; fourth, in order to find the required information easier.

Based on the research results, it is known that the PIMNAS participant students access information in the library and use facilities in the form of an online catalog (OPAC) as needed, and use simple and advanced search strategies when searching for information online using predetermined keywords. This shows that PIMNAS participating students are literate students as stated by the Association of College and Research Libraries (2000), literate students are those who create and carry out search strategies that have been designed effectively by recognizing keywords, looking for keyword similarities to obtain the required information.

Although the PIMNAS participating students searched for information using advanced searches with predetermined keywords, they did not use a search guide because the Malang State University library did not have an information retrieval guidebook on the e-journal portal that was subscribed to. This is not in line with Association of College and Research Libraries (2000) which states that literate students are those who can make tracking strategies using the available guides for the selected information retrieval system.

The purpose of using search techniques and strategies is to facilitate the process of retrieving information needed by an individual, as stated by Rupadha (2010) which states that the use of information search techniques and strategies aims to obtain information that is relevant or according to needs, avoiding search results that are too broad and too narrow.

\subsection{Information Literacy: Information Organization and Evaluation}

The fourth standard is organizing and evaluating information. The statements given to this subvariable amount to two statements.

Table 5. Statistic of Information Organization and Evaluation

\begin{tabular}{lllllll}
\hline & $\begin{array}{l}\text { Nev- } \\
\text { er }\end{array}$ & $\begin{array}{l}\text { Some- } \\
\text { times }\end{array}$ & $\begin{array}{l}\text { Of- } \\
\text { ten }\end{array}$ & Always & $\begin{array}{l}\text { To- } \\
\text { tal }\end{array}$ & $\begin{array}{l}\text { Aver- } \\
\text { age }\end{array}$ \\
\hline $\begin{array}{l}\text { Grouping information acquisition } \\
\text { based on PKM topics }\end{array}$ & - & 3 & 19 & 16 & 38 & 3.34 \\
\hline $\begin{array}{l}\text { Grouping information acquisition } \\
\text { based on recency level }\end{array}$ & 3 & 8 & 11 & 16 & 38 & 3,05 \\
\hline Overall average & $\mathbf{3 . 1 9}$ & & & & & \\
\hline
\end{tabular}

The first statement, as many as sixteen respondents (42.1\%) chose always, nineteen respondents $(50 \%)$ chose often and as many as three respondents $(7.9 \%)$ chose sometimes. The second statement, as many as sixteen respondents $(42.1 \%)$ chose always, eleven respondents $(28.9 \%)$ chose often, eight respondents $(21.1 \%)$ chose sometimes and three respondents $(7.9 \%)$ chose not ever. The average value obtained is 3.19 in the good category.

Based on the research results, the average score of the PIMNAS participant students on the fourth standard of information literacy about organization and information evaluation is categorized as good. The majority of students participating in PIMNAS are able to sort and classify the information that has been obtained based on the topic/subject and the level of the novelty of the research. This is in line with what was stated by the Association of College and Research Libraries, students who are literate are those who choose and apply standards to assess information and sources such as 
testing and comparing information from different sources that have been selected to assess reliability, validity, the accuracy, credibility and sharpness of the information obtained.

This shows that students realize the importance of organizing and evaluating the information that has been obtained, namely to make it easier or more effective in compiling it into a scientific work. This is in line with the opinion of Warlick \& Armstrong (2004) which states that the activity of organizing information is an effort to handle the amount of information stored in personal storage media and evaluating information is a person's ability to analyze information to determine its respective uses depending on the purpose of creating information and new knowledge.

\subsection{Information Literacy: Information Use and Related Issues}

The fifth standard is the use of information and related issues. The statements given to this subvariable total four statements.

Table 6. Statistics of Information Use and Related Issues

\begin{tabular}{|c|c|c|c|c|c|c|}
\hline & Never & $\begin{array}{l}\text { Some- } \\
\text { times }\end{array}$ & $\begin{array}{l}\text { Of- } \\
\text { ten }\end{array}$ & Always & $\begin{array}{l}\text { To- } \\
\text { tal }\end{array}$ & $\begin{array}{l}\text { Aver- } \\
\text { age }\end{array}$ \\
\hline $\begin{array}{l}\text { Extracting and paraphrasing informa- } \\
\text { tion }\end{array}$ & - & 4 & 19 & 15 & 38 & 3.29 \\
\hline Inclusion of references cited & - & 1 & 7 & 30 & 38 & 3.76 \\
\hline Use of citation applications & $\begin{array}{l}13 \\
2 \\
8 \\
15 \\
38 \\
2.66\end{array}$ & & & & & \\
\hline Plagiarism checker & 5 & 9 & 11 & 13 & 38 & 2.84 \\
\hline Overall average & 3.14 & & & & & \\
\hline
\end{tabular}

The first statement, as many as fifteen respondents (39.5\%) chose always, nineteen respondents $(50 \%)$ chose often and four respondents $(10.5 \%)$ chose sometimes. The second statement, as many as thirty respondents $(78.9 \%)$ chose always, seven respondents (18.4\%) chose often and one respondent (2.6\%) chose sometimes. The third statement, as many as fifteen respondents $(39.5 \%)$ chose always, eight respondents $(21.1 \%)$ chose often, two respondents $(5.3 \%)$ chose sometimes and thirteen respondents $(34.2 \%)$ chose never. The fourth statement, as many as thirteen respondents $(34.2 \%)$ chose always, eleven respondents $(28.9 \%)$ chose often, nine respondents $(23.7 \%)$ chose sometimes and five respondents (13.2\%) chose not ever. The average value obtained is 3.14 with good category.

The results showed that the fifth standard of information literacy about determining information retrieval techniques and strategies has a good average value. This can be seen from the ability of students to paraphrase a work being cited, including the cited reference sources in the bibliography. These two things are ethics in writing or creating works that must be owned by everyone who is going to make a scientific work. As the opinion of Warlick \& Armstrong (2004) which states that ethics is one of the new skills that a person must have in information literacy, ethics in information literacy is defined as how someone uses information ethically in various social contexts, one of which is writing or citing sources. which is quoted. The Association of College and Research Libraries (2000) also states that literate students are those who comply with laws, regulations, institutional policies and ethics relating to access to and use of information sources.

Even though the PIMNAS participant students were able to cite the information that was used as a reference in preparing PKM properly, there were some of them who still included a list of 
references manually or did not use citation applications such as Mendeley. This is because there is no information about the use of citation applications from the university or from lecturers.

\subsection{Information Literacy: Information Sharing and Knowledge Creation}

The sixth standard is information sharing and knowledge creation. The statements given to this sub-variable total four statements.

Table 7. Statistics of Information Sharing and Knowledge Creation

\begin{tabular}{lllllll}
\hline & $\begin{array}{l}\text { Nev- } \\
\text { er }\end{array}$ & $\begin{array}{l}\text { Some- } \\
\text { times }\end{array}$ & $\begin{array}{l}\text { Of- } \\
\text { ten }\end{array}$ & $\begin{array}{l}\text { Al- } \\
\text { ways }\end{array}$ & $\begin{array}{l}\text { Total } \\
\text { Aver- } \\
\text { age }\end{array}$ \\
\hline Review of PKM that has been prepared & - & 3 & 8 & 27 & 38 & 3.63 \\
\hline PKM presentation practice & - & 2 & 7 & 29 & 38 & 3,71 \\
\hline Shows PKM with interesting format & - & - & 4 & 34 & 38 & 3.89 \\
\hline Receive and record input & - & - & 7 & 31 & 38 & 3,82 \\
\hline Overall average & $\mathbf{3 . 7 6}$ & & & & & \\
\hline
\end{tabular}

The first statement, 27 respondents (71.1\%) chose always, eight respondents $(21.1 \%)$ chose often and three respondents $(7.9 \%)$ chose sometimes. The second statement, as many as 29 respondents (76.3\%) chose always, seven respondents $(18.4 \%)$ chose often and two respondents $(5.3 \%)$ chose sometimes. The third statement, the tendency of students to choose answers always and often with 34 respondents $(89.5 \%)$ and four respondents $(10.5 \%)$ respectively. The fourth statement, the tendency of students to choose answers always and often with 31 respondents $(81.6 \%)$ and seven respondents $(18.4 \%)$ respectively. The average value obtained is 3.76 with very good category.

Based on the research results, the average score of the PIMNAS participant students at the sixth standard of information literacy regarding information sharing and knowledge creation was categorized as very good. The majority of PIMNAS participant students review PKM before presenting it to others, presenting PKM with an attractive visual appearance, and using the feedback obtained as evaluation material in compiling subsequent scientific papers (like PKM, thesis, dissertation) to make them better. This is in line with the opinion of Setiarso (2006) which states that research is a process of creating new knowledge and becomes one of the elements of efforts in the world of education to obtain scientific solutions to human problems, therefore a research needs to be disseminated or shared so that the results the research can be known by other people and can be used as a reference by other researchers.

The Association of College and Research Libraries (2000) also states that literate students are those who perfect the process of creating a work and communicate the work effectively to others by establishing media and forms of communication that support the achievement of goals.

\section{CONCLUSION}

Based on this, it is known that the level of information literacy of PIMNAS participant students on information seeking behavior standards and information sources, technical standards and information search strategies, as well as information use standards and related issues that are categorized as good have decreased from the previous standard. This is because in the three standards, PIMNAS participant students do not get guidance from supervisors and peer tutors. These skills are carried out independently by the students participating in PIMNAS. Meanwhile, the level of information literacy of PIMNAS participant students on information needs identification standards, organizational standards and information evaluation, as well as information sharing and knowledge creation standards that get guidance from supervisors and peer tutors tends to experience an increase in average scores from the previous standard. 
Based on the research conclusions, the suggestions obtained for consideration are first, the State University of Malang library provides counseling on how to access subscribed journals to academicians at the beginning of lectures to make it easier to access subscribed journals, the counseling is in the form of an introduction to the E-JOURNAL User Education application which can be downloaded on the Play Store. Second, the library should hold information literacy training activities and make a guidebook on using citation applications to be distributed at the beginning of lectures so that students can more easily cite information. Third, students should follow scientific article writers on e-journal provider portals, for example on Google Scholar to find out the latest articles related to information needed in working on a scientific paper.

\section{REFERENCES}

ACRL, A. 2000. Information Literacy Competency Standards for Higher Education. Association of College and Research Libraries.

Batley, S. 2007. Information Architecture for Information Professionals. England: Chandos Publishing. Case, D.O. 2002. Looking for Information. London: Academic Press.

Devina, I.S. 2018. Kemampuan Literasi Informasi Mahasiswa STEI SEBI. Jakarta: Universitas Islam Negeri Syarif Hidayatullah.

Diehm, R.A, \& Lupton, M. 2014. Learning Information Literacy. Information Research, 19(1). https:// eprints.qut.edu.au/68639/1/68639.pdf.

Kemenristek-dikti. I. 2018. Pedoman Program Kreativitas Mahasiswa (PKM)Tahun 2018. https:// belmawa.ristekdikti.go.id/wp-content/uploads/2018/12/Pedoman-PKM-2018.pdf.

Krikelas, J. 1983. Information-Seeking Behavior: Patterns and Concepts. Drexel Library Quarterly, (Foundations of Library Practice), 19(2): 5-20.

Lasa, Hs. 2009. Kamus Kepustakawanan Indonesia. Yogyakarta: Pustaka Book.

Lldikti. 2018. Apakah Program Kreativitas Mahasiswa Dan Manfaatya, Yuk Simak!. Lembaga Layanan Pendidikan Tinggi Wilayah XI Kalimantan. https://ldikti11.ristekdikti.go.id/berita/351/apakahprogram-kreativitas-mahasiswa-dan-manfaatnya-yuk-simak-.

Mokhtar, M., Azura, I., Majid, S., \& Foo, S. 2004. Measuring Information Literacy in Education. In Proceeding of Conference on Information Literacy: Information, Learning, Innovation: Delivering Global Knowledge, 1-18. Brunei Darussalam.Pattah, S.H. 2014. Literasi Informasi: Peningkatan Kompetensi Informasi dalam Proses Pembelajaran. Jurnal Ilmu Perpustakaan \& Kearsipan Khizanah Al-Hikmah, 2(2): 117-28.

Purwono, P. 2008. Strategi Penelusuran Informasi Melalui Internet. Makalah tidak Dipublikasikan. Yogyakarta.

Rupadha, I.K. 2010. Teknik dan Strategi Penelusuran Informasi untuk Penulisan Karya Ilmiah. Makalah tidak Dipublikasikan.

Setiarso, B. 2006. Manajemen Pengetahuan (Knowledge Management) dan Proses Penciptaan Pengetahuan. https://ilmukomputer.org/wp-content/uploads/2006/09/bse-kmiptek.pdf.

Spink, A., \& Cole, C. 2006. Human Information Behavior: Integrating Diverse Approaches and Information Use. Journal of the American Society for Information Science and Technology, 57: 1125-35.

Sulistyo-Basuki, S. 2004. Pengantar Dokumentasi. Bandung: Rekayasa Sains.

Syahrir, S. 2013. Kemampuan Literasi Informasi Mahasiswa Program Studi Akuntansi S1 (Semester VIII/Tahun Akademik 2012/2013) Fakultas Ekonomi Universitas Hasanuddin Makassar. Skripsi. Makassar: Universitas Islam Negeri Alauddin.

UNESCO, U. 2008. Information for All Programme (IFAP): Towards Information Literacy Indicators. http://www.uis.unesco.org/ template/pdf/cscl/InfoLit.pdf. 
Warlick, D., \& Armstrong, S. 2004. The New Literacy: The 3 Rs Evolve into the 4 Es. Technology \& Learning, 25 (2): 1-9.

Wilson, T.D. 2000. Human Information Behavior. Informing Science The International Journal of an Emerging Transdiscipline, 3(2): 49-56. 